Diva Ayunindya Fatharani ${ }^{1}$, Moses Glorino Rumambo Pandin ${ }^{2}$

Universitas Airlangga

Jl. Airlangga 4-6 Surabaya - 60285 Indonesia

diva.ayunindya.fatharani-2020@fib.unair.ac.id ${ }^{1}$, moses.glorino@fib.unair.ac.id ${ }^{2}$

\title{
BOOK REVIEW :
}

Millenial \& Turnover ; The Art of Adapting with New Normal

(MILLENNIAL \& TURNOVER ; Seni Beradaptasi dengan New Normal)

Sony Tan, Kang Maman : Jakarta: 2020: 978-602-481-450-2: 158 halaman

Millennial \& Turnover was written to discuss the Turnover phenomenon in Millennial employees. Turnover is the process of replacing one worker with another worker for a reason. It provides clear explanations from both millennial employees and human resources or their leader's perspective about a positive working environment.

The book is intended for the public to read. However, because it discusses the work environment in companies, it is said to be more specialized in millennial employees or generation $\mathrm{Y}$ and Human Resource or generation $\mathrm{X}$ leaders.

The book explains various common problems that exist in the labor world. One of the common problems is Turnover. The new information I acquired from the book stated that the current generation is divided into three, generation $X$ was born between 1961-1980, generation Y or millennial was born between 1981-1995, and generation $\mathrm{Z}$ was born from 1996-now. It has a decisive view of the millennial generation. Both writers have strong traces of the labor world in the millennial generation. Sony Tan is a practitioner in Human Resource (HR). His thesis examined the satisfaction of communication and organizational commitment to millennial group workers. Maman Suherman, or whom we know as Kang Maman, is a literacy activist whose focus is on millennials. In addition, Kang Maman has vast experience in the creative and writing field as both a journalist and an active figure on television.

The book is exciting and needs to be reviewed so we will be able to see how far it can open and widen millennial or gen Y job applicants and gen X leader's minds. The generation gap is the main problem that is presented in it. It needs to be reviewed to assess whether or not it is sufficient for the readers' needs.

Millennial \& Turnover, a writing collaboration between Sony Tan and Maman Suherman, answers all questions from the previous generation, known as generation $\mathrm{X}$, in facing the Millennial generation, especially in the labor world. It is considered one of the best choices for generation $\mathrm{Y}$ and generation $\mathrm{X}$ because readers can see the issue from two different points of view. Not only that, it answers various questions about why the millennial worker turnover rate in companies is high.

The book is a Q\&A between Sony Tan and Maman Suherman regarding the Millennials' character tendency to work fast, practical, and without being bound by complicated rules. It also states that the millennial generation is critical and able to quickly access the internet so that all sorts of information are easy to obtain. Specifically, It discusses Human Resources in the new standard era, particularly the art of adapting and working together between generations.

For millennials or generation X, It solve communication problems between generations. In the labor world, people can achieve success if communication between these organizations is effective. The success of this relationship depends on communication that focuses on listening to one another. This effective organizational communication can make subordinates feel safer and more comfortable in their work atmosphere to avoid Turnover. Chapter IV, "The Importance of Superior-Subordinate Relationships" and chapter V, "Organizational Communication," explain the form of good relations and communication in the labor world that can be classified as a solution to overcome intergenerational communication. 
The book can influence readers through the provided discussions and data. Because it was written to reveal facts about the labor world, it opens the readers' minds. Readers understand what is in the labor world: the problems and the solutions to overcome them. Therefore, job applicants will be able to prepare themselves for work ethics.

The generation gap causes the central issue in the discussion. A generation gap in Indonesian is known as kesenjangan generasi according to KBBI (Kamus Besar Bahasa Indonesia), is the difference in values, attitudes, and behaviors between two groups of generations. One example given by Sony Tan is the problem of communication organization. In his book, he mentioned that generation X prefers meetings to discuss something urgent. In contrast, Sony Tan explained that the $\mathrm{Y}$ or millennial generation prefers communication via WhatsApp for urgent matters.

The examples described by Sony Tan are not merely words transferred from mouth to mouth but also a personal experience. It should be remembered that Sony Tan is a practitioner in Human Resource (HR). All explanations of the cause and effect of the generation gap problem are helpful for those who have read them. Many employers and HR have given excellent responses to the book.

For leaders, it gives a powerful message: avoid assumptions, give genuine dialogue with all teams, build trust, and most importantly: be a Role Model who inspires others to live out the company values. Josef Bataona, Former HR Director of Unilever, Danamon, and Indofood; Book Author; Blogger; and Executive Coach - not many people can understand, let alone reveal the secret behind the complicated GENERATION GAP. I believe that the book will become a guide for many people who care about or are interested in today's young generation-Andreas Nawawi, Founder of Generation Z Entrepreneur Community

NurKhazanah; Property Consultant; and Senior Sales Advisor. The tips in the book are very applicable and exciting because they are presented straightforwardly in a conversation with Kang Maman. I highly recommend the book for anyone who wants to have a harmonious and productive relationship with the younger generation-Dr. Muhammad Faisal, Indonesian Millennial Researcher; Author of Generation Phi and Generation Return to Roots.

Book's writing style is presented in the form of a podcast. The discussion in it concentrates on the main problem of the generation gap: its causes and its effects. The authors' explanations do not often get out of topic, making it easier for readers to understand the reasoning behind one problem or topic discussion. In addition, it is not subjective. Hence, it does not see from one side of superiors or subordinates why it can convince readers. It fits the style, organization, and size of its purpose.

Book's story line also elaborates on the generation gap in the labor world. There was no study, facts, or ideas that the authors ignored. The information in it is objective and based on experience. It also lists some questions that job applicants commonly ask regarding employers, the work system, the leave system, and the labor world.

Sony Tan and Kang Maman intend to prepare readers for ethics in the labor world. Ethics is a lesson that we have never adequately received in school or university, and we learn ethics based on observation. Therefore, it is essential to provide an overview to job applicants on being ethical at work. The discussion of work ethics in it is written explicitly, so there is no difficulty for readers to understand it.

There are many advantages to the book, but there are still drawbacks. It is targeted at a working audience, but there will be nothing wrong with students reading the book. Therefore, it needs to clarify again in working terms.

I suggest that the authors invite millennial workers to join in on the discussion. By asking millennials to discuss the issue together, perhaps the recommendations on the synopsis can be more trusted for readers because, as seen from the sentences in the recommendations, it was not written by generation Y or millennials.

Diva Ayunindya Fatharani \& Moses Glorino Rumambo Pandin Universitas Airlangga 


\section{REFERENCE :}

Sony Tan dan Kang Maman. (2020), "Milenial \& Turnover ; Seni Beradaptasi dengan New Normal”. Jakarta: Gramedia Pustaka Utama

\section{AUTHORS SHORT-BIODATA}

1. Sony Ten is a man who was born in Sibolga and earned the title of Accountant from the Faculty of Economics, University of North Sumatra (USU) in 1991. In 2005, he was appointed as CEO of PT Digital Media Technology (PMA), a company engaged in the optical disc industry. He holds a Masters in Psychology from the Faculty of Psychology, University of Atma Jaya Jakarta, in 2018. His thesis examines communication satisfaction and organizational commitment to millennial group workers.

2. Maman Suherman or better known as Kang Maman, was born in Makassar. He is a literacy activist who focuses is on Millennials and has a wide range of experience in the writing and creative fields both as a journalist and as an active person on television. From Kang Maman's literacy, dozens of television program scripts were born. His experience as a producer and director has resulted in dozens of programs broadcast on various national TV stations. 